\title{
THE PHYSICIAN AND WITCHCRAFT IN RESTORATION ENGLAND
}

\author{
by
}

\author{
GARFIELD TOURNEY
}

THE YEAR of 1660 witnessed important political and scientific developments in England. The restoration of the monarchy and the Church of England occurred with the return of Charles II after the dissolution of the Commonwealth and the Puritan influence. The Royal Society, after informal meetings for nearly fifteen years, was established as a scientific organization in 1660 and received its Royal Charter in 1662. During the English revolution, and for a short time during the Commonwealth, interest in witchcraft mounted. Between 1645 and 1646 Matthew Hopkins acquired the reputation as the most notorious witch-finder in the history of England. ${ }^{1}$ His activities in Essex and the other eastern counties led to the execution of as many as 200 witches. In Suffolk it is estimated that he was responsible for arresting at least 124 persons for witchcraft, of whom 68 were hanged. The excesses soon led to a reaction and Hopkins lost his influence, and died shortly thereafter in 1646.

There then was a continuing decline in witchcraft persecutions, and an increasing scepticism toward the phenomena of witchcraft was expressed. Scepticism was best exemplified in Thomas Hobbes' (1588-1679) Leviathan, published in $1651 .^{2}$ Hobbes presented a materialistic philosophy, emphasizing change occurring in motion, the material nature of mental activity, the elimination of final causes, and the rejection of the reality of spirit. He decried the belief in witchcraft and the supernatural, emphasizing throughout a naturalistic and materialistic philosophy. Many believed that his approach sorely tried the religious philosophy and faith of the time, and much criticism of Hobbes was forthcoming. ${ }^{3}$

The Aristotelian interpretation of the natural sciences and the scholastic philosophy which dominated the universities were actively attacked in a pamphlet Academiarum Examen by John Webster (1610-1682) in 1654." Webster professed to follow Bacon and pressed for a new system which seemed to embody Bacon's approach to science, although he wanted to combine 'the new philosophy' with alchemical, astrological and various occult ideas. Joseph Glanvill (1636-1680) in 1661 in The Vanity of

1 Montague Summers, The Discovery of Witches. A Study of Master Matthew Hopkins commonly call'd Witch Finder Generall, London, Cayne Press, 1928. See also Alan Macfarlane, Witchcraft in Tudor and Stuart England, London, Routledge \& Kegan Paul, 1970, Appendix I, 'Abstracts of Essex witcheraft cases, $1560-1680^{\circ}$.

2 Thomas Hobbes, Leviathan, ed. by Michael Oakeshott, Oxford University Press, 1946. Hobbes wrote, 'As for witches, I think not that their witchcraft is any real power; but yet that they are justly punished, for the false belief they have that they can do such mischief, joined with their purpose to do it if they can.' p. 12.

- Samuel I. Mintz, The Hunting of Leviathan, Cambridge University Press, 1962.

- John Webster, Academiarum Examen or the Examination of Academies, London, 1654. For discussion of this pamphlet see Martha Ornstein, The Role of Scientific Societies in the Seventeenth Century, University of Chicago Press, 1928, pp. 243-44, and Margery Purver, The Royal Society: Concept and Creation, Cambridge, Mass., M.I.T. Press, 1967, pp. 65-67. 


\section{Garfield Tourney}

Dogmatizing ${ }^{5}$ also criticized the paralysing effects of the Aristotelian approach to science, and shortly after this became a Fellow of the Royal Society and one of its most literate propounders. Interestingly enough, Webster, a divine and later a physician, and Glanvill, a divine and philosopher, initially took the same approach in attacking Aristotelianism. However, Glanvill was to become the most fluent defender of the belief in witchcraft, and Webster its most profound critic during the Restoration period. Webster, in his earlier critique of Aristotle, accepted occult phenomena while Glanvill rejected astrology and made no mention of witchcraft. Later, however, Glanvill used scepticism to reinforce his defence of the belief in witchcraft. ${ }^{\circ}$

On the basis of these historical developments one might have anticipated a continuous decline in cases of witchcraft and concern for the subject after 1660 . However, this period was a tremendous increase in the literature on witchcraft which discussed extensively both its theory and practice. ${ }^{7}$ A number of witchcraft cases occurred, many in which physicians were called to make testimonies. Many of the prominent physicians and scientists of the day maintained an interest and belief in witchcraft, even though they were active in the Royal Society and made important contributions to medicine and science. The concern and alarm regarding witchcraft occurred on a wide basis in England, and in many cases followed the pattern of the earlier trials. In the 1660s there was a rise in the number of such cases, with a dropping off during the 1670 s, and by the close of the 1680 s accounts were rare. An increased number of strange diseases called 'possession', which were characterized by convulsive and hysterical phenomena, often occurred in young girls and boys. These were believed to be diseases caused by the devil. The physician was often consulted as an expert witness in order to diagnose the illness and its possible diabolic cause. ${ }^{8}$

Scepticism about witchcraft was regarded by many as a test of the philosophy and religious faith of the day. ${ }^{\circ}$ In rejecting a belief in the reality of spirits and devils one was in conflict with Scripture, legal traditions, and the polemics of many authorities. Disbelief in spirits and devils was equated with atheism, and mechanistic explanations could not be substituted for religious vitalism. Hobbes' viewpoint was opposed by many, and particularly by the Cambridge Platonists Henry More (1614 $1680)^{10}$ and Ralph Cudworth (1617-1688). ${ }^{11}$ His philosophy was thought to undermine all religious belief. The Cambridge Platonists believed in a spirit world, in absolute ideas, free will, and absolute and eternal morality as well as a psychology based upon the doctrine of innate goodness and selflessness.

Closely associated with More and Cudworth was Glanvill, the active propagandist for the Royal Society, but also the most literate of the apologists of witchcraft. He

- Joseph Glanvill, The Vanity of Dogmatizing, London, 1661.

- H. R. Trevor-Roper, Religion, the Reformation and Social Change, London, Macmillan, 1967, p. 180.

'Wallace Notestein, A History of Witchcraft in England, Washington, American Historical Association, 1911, pp. 254-312.

- C. L'Estrange Ewen, Witchcraft and Demonianism, London, Heath Cranton, 1933, pp. 130-36.

- Richard S. Westfall, Science and Religion in Seventeenth-Century England, New Haven, Yale University Press, 1958.

10 Aharon Lichtenstein, Henry More: The Rational Theology of a Cambridge Platonist, Cambridge, Mass., Harvard University Press, 1962, pp. 32-41.

${ }_{11}$ J. A. Passmore, Ralph Cudworth: An Interpretation, Cambridge University Press, 1951, pp. 11-14. 


\section{The Physician and Witchcraft in Restoration England}

wrote extensively on the subject, beginning in $1666 .{ }^{12}$ As a close friend of the Cambridge Platonists, as chaplain-in-ordinary to Charles II, and a strong advocate of the Royal Society, he exerted a tremendous influence in the intellectual community of Restoration England. In 1662 he became a member of the Royal Society. Glanvill believed that the methods of science could be applied to studying supernatural phenomena, which he thought should be an area of great interest for the Society.

Questions were being raised regarding many aspects of religion, and with the Restoration there was a slowly developing religious toleration. The achievements of natural science and medicine were gaining wide acceptance and growing in prestige. With the emphasis on a mechanical concept of nature, miracles and the reality of divine providence were questioned. During the political turmoil of the Revolution and the Commonwealth many left-wing sectarian sects developed and enthusiasm in religion became pronounced. ${ }^{13}$ The ills of society continued to be related to heresy and to the nonconformists. ${ }^{14}$ Such ideas and practices were criticized by many of the philosophers and scientists who were seeking the rational foundations of religion, which they called 'natural religion'. Ideas of protestantism conformed to many aspects of the natural science viewpoint, as seen in the contempt for medieval scholasticism, the resemblance of a Calvinist God to the watchmaker God of the mechanical universe, and in Robert Boyle's (1627-1691) portrait of the Divine Mechanic constructing his inexorable machine. ${ }^{15}$ The virtuosi of the Royal Society came from a number of religious backgrounds, including Roman Catholic. They avoided religious controversy, but saw in their work a confirmation of their religious beliefs although they came to emphasize rational, demonstrable elements at the expense of suprarational mysteries. Many of the virtuosi devoted themselves to religious works as well as scientific ones, the former occurring as a reaction to Hobbes and the developing materialistic philosophy. They realized certain dangers in science, such as that of intellectual arrogance leading one to prefer one's own word to that of God, and the fact that science might end in pure materialism. The virtuosi repeatedly asserted that the study of nature gave evidence for the existence of God and his works.

The two most influential publicists for the Royal Society were Thomas Sprat $(1635-1713)^{16}$ and Glanvill. ${ }^{17}$ Sprat attacked enthusiasm and superstition, and avoided any discussion of witchcraft, while Glanvill made a serious study of witchcraft phenomena. In Glanvill's first discussion of witchcraft ${ }^{18}$ he emphasized that the repudiation of witchcraft could be equated with atheism. He felt that with the

12 Joseph Glanvill, A Philosophical Endeavor towards the Defense of the Being of Witches and Apparitions, London, 1666. Some Philosophical Considerations Touching the Being of Witches, 2nd ed., London, 1667, A Blow at Modern Sadducism, London, 1668, (3rd ed., with the drummer of Tedworth story); Saducismus Triumphatus, London, 1681 (More's posthumous edition), reprinted $1682,1689,1700,1726$. For bibliographic discussion of Glanvill's works on witchcraft, see Coleman O. Parsons, 'Glanvill's Witch Book and Its Influence', introduction to facsimile reprint of Saducismus Triumphatus, 1689. Gainsville, Scholars' Facsimiles and Reprints, 1966, pp. vii-xiii.

${ }_{13}$ M. V. De Porte, 'Introduction' to facsimile reprint of Henry More: Enthusiasmus Triumphatus, Los Angeles, University of California Press, 1966, pp. i-ix.

14 Trevor-Roper, op. cit., pp. 190-92.

15 Westfall, op. cit., pp. 40-48.

16 Thomas Sprat, History of the Royal Society, London [1667]. Edited by Jackson I. Cope and Harold Whitmore Jones, St. Louis, Washington University Press, 1959.

${ }_{17}$ Joseph Glanvill, Scepsis Scientifica, London, 1665; Joseph Glanvill, Plus Ultra, London, 1668; Jackson I. Cope, Joseph Glanvill: Anglican Apologist, St. Louis, Washington University Studies, 1956.

${ }^{18}$ See footnote 12. 


\section{Garfield Tourney}

employment of the tool of scientific investigation and study witchcraft would be vindicated, and that the belief in spiritual being would then strengthen the foundations of Christianity. He regarded atheists, Sadduces and Hobbists as all of the same species.

The Royal Society had many diverse members, but many outstanding physicians and scientists of the day never established membership, such as Sir Thomas Browne (1605-1682) and Thomas Sydenham (1624-1689). In fact, many of Sydenham's philosophic ideas were in basic contrast to those of the virtuosi of the Royal Society. He emphasized rational laws in contrast to mechanical ones, accepted the reality of spirit, supported many ideas of Aristotle and rejected the mechanical concept of nature. ${ }^{19}$ Browne maintained his interest in the supernatural and was to give testimony at one of the most famous witchcraft trials. Browne always remained on the fringe of the scientific movement; for him the visible world was but a picture of the invisible one, and his approach to nature was certainly more mystical than scientific. In his Religio Medici, published in 1642, he stated 'that for my own part, I have ever belieeved, and doe now know, that there are Witches; they that doubt of these, doe not onely deny them, but Spirits; and are obliquely and upon consequence a sort, not of Infidels, but Atheists . . . I hold that the Devil doth really possesse some men, the spirit of melancholy others, the spirit of delusion others $\ldots{ }^{20}$ Such a belief was repeatedly expressed in many of Browne's later works. ${ }^{21}$

The celebrated physician became involved as an expert witness in 1664 at the Bury St. Edmund's trials. At that time Browne was nearly sixty years old, had attained prominence as a physician and writer, and continued practice in Norwich. Two women, Rose Cullender and Amy Duny, had been indicted for bewitching some children, who were suffering from various hysterical symptoms, such as fits, blindness, vomiting of pins and nails, and fitted the picture of possession. The trial was only later detailed in 1682, ${ }^{22}$ but most scholars believe that it was generally known throughout England at the time of its occurrence. ${ }^{23}$ No witnesses were examined on behalf of the accused women, and they were not represented by council. The famous judge, Sir Matthew Hale (1609-1676), heard the case, and when he charged the jury he stated that there was no doubt that there were such creatures as witches and told the twelve men to observe strictly the evidence. During the trial the three children fell into strange, violent fits, shrieking in a most sad manner, but they could not in any way give instruction to the court as to the nature of their disorder. Along with parents and relatives, they accused Rose Cullender and Amy Duny of bewitching them and often cried out against them in their fits. A number of witnesses were called, including Browne. The following was written about his testimony:

19 Westfall, op. cit., pp. 102-3.

${ }^{20}$ Thomas Browne, Religio Medici. In Geoffrey Keynes (ed.), The Works of Sir Thomas Browne, vol. 1, London, Faber \& Faber, 1964, pp. 40-41.

${ }_{21}$ Thomas Browne, Pseudodoxia Epidemica. In Geoffrey Keynes (ed.), The Works of Sir Thomas Browne, vol. 2, London, Faber \& Faber, 1964, pp. 69, 392; Thomas Browne, Miscellaneous Notes from Commonplace Books. In Geoffrey Keynes (ed.), The Works of Sir Thomas Browne, vol. 3, London, Faber \& Faber, 1964, p. 293.

"2 Reprinted in Thomas Baly Howell, Cobbett's Complete Collection of State Trials, vol. 6, London, T. C. Hansard, 1810, pp. 647-702.

${ }^{23}$ Notestein, op. cit., pp. 261-67. 


\section{The Physician and Witchcraft in Restoration England}

There was also Dr. Browne of Norwich, a person of great knowledge; who after this evidence given and upon view of the three persons in Court, was desired to give his opinion, what he did conceive of them: and he was clearly of opinion, that the persons were bewitched; and said, that in Denmark there had been lately a great discovery of witches, who used the same way of afflicting persons, by conveying pins into them, and crooked as these pins were with needles and nails. And his opinion was, That the devil in such cases did work upon the bodies of men and women, upon a natural foundation, [that is] to stir up, and excite such humours superabounding in their bodies to a great excess, whereby he did in an extraordinary manner afflict them with such distempers as their bodies were most subject to, as particularly appeared in these children; for he conceived that these swooning fits were natural, but nothing else but that they call the mother, but only heightened to a great excess by the subtlety of the devil, co-operating with the malice of these which we term witches, at whose instance he doth these villanies. ${ }^{24}$

Francis Hutchinson (1660-1739) in his Historical Essay Concerning Witchcraft, ${ }^{25}$ published in 1718, maligned Browne for his testimony and emphasized that it must have been very influential on the jury to gain their acceptance of the questionable evidence presented against the accused persons. Browne gave the authority through his references on similar cases in Denmark and not on the basis of any clinical experience; after a half-hour deliberation by the jury a verdict of guilty was brought in and the two women were hanged one week later. Many others have also regarded Browne as being extremely credulous because of his belief in witchcraft, astrology, alchemy and magic. ${ }^{26}$ However, Browne's opinions were not at all unusual for many physicians of this period. Like most of his contemporaries, he believed in witchcraft and that the denial of such a belief was to deny the existence of the spiritual world and was hence atheistical. ${ }^{27}$ As one reviews the original report one is aware that Hutchinson magnified and misinterpreted the part that Browne played in the trial. Browne's words may have confirmed the sentiment of the courtroom and strengthened the case of the prosecution, but he by no means committed himself to the guilt of the parties. He initially diagnosed the case as the mother or hysteria but did not reject the hypothesis of the devil's possible contribution to the states of possession. As Kittredge has stated about his beliefs and testimony:

Browne has been much blamed for his dictum, but there is nothing unreasonable or unscientific in it, if one merely grants the actuality of demoniacal obsession and possession, which was then to all intents and purposes an article of faith. If the devil can work upon our bodies at all, of course he can intensify any natural fits or spasms from which we happen to be suffering. Thus Browne's diagnosis of the disease in this case as hysteria, by no means excluded the hypothesis of maleficium, but most modern writers refuse to discuss such subjects except de haut en bas from the vantage ground of modern science. ${ }^{28}$

An example of firm belief in witchcraft in a physician is seen in William Drage (1637?-1669), a medical writer and apothecary who practised at Hitchin, Hertfordshire. In 1664 he first published A Physical Nosonomy; Or A New and True Description of the Law of God (Called Nature) in the Body of Man. To Which is Added a Treatise

\footnotetext{
${ }^{24}$ Howell, op. cit., p. 697.

${ }^{25}$ Francis Hutchinson, An Historical Essay Concerning Witchcraft, London, 1718, pp. 118-21.

26 James Hendrie Lloyd. 'Sir Thomas Browne and the witches', Ann. med. Hist., 1928, 10, 133-37; Dorothy Tyler, 'Sir Thomas Browne's part in a witchcraft trial', Anglia, 54, 1930, 179-95.

${ }^{27}$ John Knott, 'Medicine and witchcraft in the days of Sir Thomas Browne', Brit. med. J., 1905, ii, 951-61, 1046-49; Malcolm Letts, 'Sir Thomas Browne and witchcraft', Notes and Queries, 1912, 5, 221-23; Jeremiah S. Finch, Sir Thomas Browne, New York, Henry Schuman, 1950, pp. 214-18.

${ }_{28}$ George Lyman Kittredge, Witcheraft in Old and New England, Cambridge, Mass., Harvard University Press, 1929, pp. 334-35.
} 


\section{Garfield Tourney}

of Diseases from Witchcraft. ${ }^{29}$ This was reprinted in 1665 as Daimonomagia and editions subsequently appeared in 1666 and 1668 . Drage was a profound believer in witchcraft and astrology, and a disciple of Dr. James Primrose who was one of Harvey's strong opponents. He was familiar with Dr. Woodhouse, a popular witch doctor of the time. In a study of a case of possession, Drage reached the following conclusions:

The Devil can cause all Diseases that are Natural, but Nature cannot cause all Diseases that are Diabiolical; the Devil quatenus, a Spirit, can do all manner of mischief; but Quatenus Inferour, he cannot do all the evil he will and Quatenus Evil, he will not do all the good he can. They that leap five or six yards, that speak Tongues they never learned; that foretel things to come; that are stronger than four or five men; that fly, or stand in the Air; or run up Walls without the use of their hands; or have their Face bent quite behind them, so long remaining, Consideratis considerandis, must be possessed of Spirits; but they that are not thus handled may be possessed of Spirits. ${ }^{20}$

He described in detail the case of a girl, Mary Hall of Gadsden, who was reputed to be possessed by two devils in 1664 . These evil spirits frequently spoke out from her. This girl attracted considerable interest, particularly that of Dr. Woodhouse, who was well known for treating possession, and Richard Saunders, the astrologer and chiromancer, who also practised medicine. In the examination of witches he accepted as positive evidence their rejection by water, the presence of extra teats, and their inability to call upon God for help. Diagnostic signs of possession include strange and bizarre convulsions, inexpressible torments, complaints by the subject of a woman or man suspected of being a witch, speaking strange tongues that the individual could not have learned, predicting the future, hoarding strange objects such as pins and needles, descending of imps or young spirits into persons, bewitchment by voices, eyes (fascination), ointments and powders. He recommended the treatment for the bewitched to include making the witch suffer, to call on God, and to use specifics which are antipathetic to demons. The witch could also be forced to break the enchantment through appropriate ceremony, to transfer the disease to herself or some other animal, or to reveal the charms that caused the disease. Finally, he emphasized that if the witch is put in prison, Satan abandons her, and the magic power expires. At times, of course, execution may be necessary to reach these ends. In regard to disease, he concludes: 'Therefore whatsoever Supernatural and Spiritual may be proved to arise from the common force, and usual order of natural things, is thereby proved to be Natural; and whatsoever cannot be solved by the ordinary force, and usual course of any Natural Causes is thereby proved Supernatural and Spiritual'. ${ }^{31}$

An increasing amount of literature on the subject of witchcraft appeared. In 1665 Reginald Scot's (1538-1598) Discovery of Witchcraft was re-published, ${ }^{32}$ not with any aim at presenting his sceptical viewpoint, but rather at fostering the belief in witchcraft through gross distortion of several chapters of the text and the addition of a few credulous works. As mentioned above, Glanvill's first work on witchcraft

${ }^{20}$ London, 1664.

so William Drage, A Relation of Mary Hall of Gadsden, introduction by W. B Gerish. Bishops Stortford, Hertfordshire Folklore, 1912, pp 24-25.

81 Ibid., p. 26.

32 Reginald Scot, The Discovery of Witchcraft, London, 1665. (1st ed., London, 1584). 


\section{The Physician and Witchcraft in Restoration England}

appeared in 1666, with reprintings and additions appearing in $1667,1668,1681$, $1682,1689,1700$ and $1726 .{ }^{23} \mathrm{He}$ described a witch as follows:

... a witch is one, who can do or seems to do strange things, beyond the known Power of Art and ordinary Nature, by vertue of a Confederacy with Evil Spirits ... The strange things are really performed, and are not at all Impostures and Delusions. The witch occasions, but is not the Principal Efficient, she seems to do it, but the Spirit performs the wonder, sometimes immediately, as in Transportations and Possessions, sometimes by applying other Natural Causes, as in raising Storms, or inflicting Diseases, sometimes using the Witch as an Instrument, and either by the Eyes or Touch, conveying Malign Influences: and these things are done by vertue of a Covenant, or Compact betwixt the Witch and an Evil Spirit."

Glanvill was a personal friend of Robert Boyle and in Boyle's correspondence with Glanvill his interest in the subject of witchcraft is apparent in his support for Glanvill's criticisms of Webster's work. ${ }^{25}$ Much of Glanvill's book represents a survival of older discussions of the witchcraft problem based on theological grounds, as well as a reaction to the materialistic philosophy of Hobbes.

In 1668 Glanvill included in his work for the first time the story of the Demon of Tedworth, a notorious witch disturbance which he investigated personally. ${ }^{36}$ In the posthumous edition of his work, appearing in 1681, he elaborated a collection of witch stories which were used to support the belief in the form of testimonial evidence. He did admit that many witch stories were plain fraud, but this did not discredit such testimony altogether. Henry More, who amended the earlier editions of Glanvill's work in the one of 1681, emphasized that such individuals as Boyle and Willis believed in witchcraft. Glanvill was not subject to a naive credulity, but he thought of his collection of stories as a 'cautious, and faithful history made of those certain and uncommon appearances' ${ }^{\prime 37}$ which he had urged as a possible project for investigation by the Royal Society. Because of this work, he has been regarded by some as the father of psychical research. ${ }^{38}$

Let us now look at the opinions of the two most famous physicians of the period, Thomas Sydenham (1624-1689) and Thomas Willis (1621-1673). Sydenham's great discoveries were in clinical medicine and he emphasized the physician's main task of treating the sick rather than experimenting in such basic sciences as anatomy, chemistry and botany. He opposed the use of the microscope in that man's faculties were so shaped by God only to observe the outer husk of things rather than their internal configuration. Sydenham has not expressed himself regarding the problem of witchcraft and in his extensive discussion of hysteria he emphasized the natural disease concept, ascribing the cause to irregular motion of the natural spirits. In hysteria, or the fits of the mother, he felt that the strangulation of the womb caused a copious collection of the spirits in the lower belly, with a rushing with violence to other

See footnote 12 .

24 Joseph Glanvill, Saducismus Triumphatus, London, 1689, pp. 269-70.

ss Robert Boyle, 'Letter to Glanvill, September 18, 1677', Works, vol. 5, ed. by V. Birch, London, 1744, pp. 633-34.

'George Edelen, 'Joseph Glanvill, Henry More, and the Phantom Drummer of Tedworth', Harvard Library Bulletin, 1956, 10, 186-92.

${ }^{27}$ Moody E. Prior, 'Joseph Glanvill, witchcraft, and seventeenth century science', Modern Philology, 1932, 5, 166-93.

st Staniey Redgrave and I. M. L. Redgrave, Joseph Glanvill and Psychical Research in the Seventeenth Century, London, William Rider, 1921. 


\section{Garfield Tourney}

parts of the body and expressed in the facies. ${ }^{39} \mathrm{He}$ also rejected the astrological and alchemical beliefs of the time. However, he was very much interested in the work of Valentine Greatrakes (1628-1666), who cured patients by stroking them. Although he realized that Greatrakes' healing mission arose from a peculiar delusion, he was very much impressed by the curative powers of Greatrakes and urged his friend Oldenberg of the Royal Society to communicate his enthusiasm to Boyle, who remained unimpressed. ${ }^{40}$ Incidentally, Glanvill was very much taken by the Irish healer and participated with him in seances along with Lady Anne Conway, the "heroine pupil' of Henry More. ${ }^{41}$

Willis made a number of notable contributions to cerebral anatomy and clinical medicine, including a more modern concept of epilepsy as differentiated from a broad group of convulsive phenomena ranging from tetanus to hysteria. However, in commenting upon the name 'Sacred Disease' and the belief in demoniacs as expressed in the Gospel, he admitted that convulsive distempers could be caused by witchcraft, and a differential diagnosis was necessary. ${ }^{42}$

That convulsive distempers are sometimes excited by witcheraft, is both commonly believed and usually affirmed by many Authors worthy of Credit: and indeed, as we do grant that very often-times most admirable passions are produced in the humane body by the delusions of the Devil, forasmuch as he, to cause wonders, by which he might rule, by the subtlety of working, insinuates to the sensitive soul, or the constitution of the animal spirits, heterogeneous Atoms of little Bodies, and so adds now spurs or pricking forward, and now casts chains on its functions, and now carries them to mischief: also by some means he enters himself into the humane body, and as it were another more mighty soul, is stretched thorow, it actuates all the parts and members, inspires them with an unwonted force, and governs them at his pleasure: and incites to the perpetrating of most cruel and supernatural wickednesses: yet all kind of convulsions, which besides the common manner of this disease appear prodigious, ought not presently to be attributed to the enchantments of Witches, nor is the Devil presently or always to be brought upon the stage. ${ }^{2 s}$

One can see that many convulsive phenomena for Willis were related to natural diseases, but furthermore, witchcraft was to be suspected firstly if the patient performed contortions or gesticulations of the extremities and body that no sound man could mimic or any tumbler could imitate, and secondly, if such strength be shown that surpasses all human force. The Sabbath and the transvection of witches were explained as dreams imprinted by the devil.44

Of those opposed to witchcraft, John Wagstaffe (1633-1677) in 1669 and John Webster in 1677 made the most outstanding contributions. Wagstaffe's work, The Question of Witchcraft Debated, ${ }^{45}$ was first printed as a reaction to the works of Joseph Glanvill and the current beliefs in witchcraft. Wagstaffe, the tipsy Oxford scholar, was not medically oriented in his criticism and placed the origins of witchcraft in heathen fables; he emphasized that coincidence and jugglery accounted for such

so John Swan (ed.), The Entire Works of Dr. Thomas Sydenham, London, 1753, pp. 417-18.

¿ Kenneth Dewhurst, Dr. Thomas Sydenham, London, Wellcome Historical Medical Library, 1966, pp. 31-32.

¿1 Ferris Greenslet, Joseph Glanvill, New York, Columbia University Press, 1900, pp. 66-67.

co Owsei Temkin, The Falling Sickness, Baltimore, Johns Hopkins Press, 1945, p. 210.

43 Thomas Willis, A Medical Philosophical Discourse of Fermentation or, of the Intestine Motion of Particles in Every Body, London, 1680, p. 43.

« Hansruedi Isler, Thomas Willis, New York, Hafner, 1968, p. 160.

4s London, 1669. 


\section{The Physician and Witchcraft in Restoration England}

phenomena. He was disliked by a number of his colleagues, and about him it was stated that "In person he was "a little crooked man of a despicable presence," and his book on witchcraft created much mirth among the wits of Oxford, as he himself looked like a little wizard'.46 His work threw doubt on the truth of the alleged instances of contracts between spirits and men. He stated they were 'ridiculously absurd, and some of them so impossible for all the devils in hell to accomplish'. He considered that the stories of witches were 'partly founded in mistaken interpretations of Scripture, partly in the knavish and gainful impostures of some men, partly in the vain, foolish credulity of other men.' After his work was assailed by Meric Casaubon ${ }^{47}$ and others, it was re-issued in the second edition in 1671.

Webster, a one-time minister and later a physician practising in Yorkshire, best exemplified the opposition in his treatise The Displaying of Supposed Witchcraft, which appeared in 1677.48 Webster, born in 1610, was ordained as an Anglican minister about 1632 . He was later a chaplain and surgeon in the parliamentary army. He initially became famous as a preacher in the 1650s, but in 1657 he gave up the ministry for the study of metallurgy and the practice of medicine. As a physician Webster was a strong supporter of Harvey's ideas. Webster's work was primarily directed against those of Glanvill and Casaubon. He was by no means a scientific rationalist, although he emphasized the effects of witchcraft to be natural and not diabolical in origin.

His work on metallurgy, Metallographia, appeared in $1671,{ }^{40}$ and belongs as much to the history of alchemy as it does to chemistry. He accepted the theory of transmutation of metals and approved of many of the mystical writers on the subject, such as Arnold of Villanova, Raymond Lull, Paracelsus, Van Helmont and Basil Valentine. Interestingly enough, he makes no mention of Boyle in this work, although he does refer to the Royal Society and Boyle's activities in the work on witchcraft.

Webster admitted that there were witches-that is, individuals who for gain and vainglory attempt to do things by hidden and occult means, but are basically 'Cheaters, Deceivers and Couseners' ${ }^{50}$ In many cases he expressed a definite medical orientation and ascribed many of the symptoms of the witches and the possessed to melancholy.

And as there are a numerous crew of active witches, whose existence we freely acknowledge; so there are another sort, that are under a passive delusion, and know not, or at least do not observe or understand, that they are deluded or imposed upon. These are those that confidently believe that they see, do, and suffer many strange, odd, and wonderful things, which have indeed no existence at all in them, but only in their depraved fancies, and are merely melancholiae figmenta. And yet the confessions of these, though absurd, idle, foolish, false and impossible, are without all ground and reason by the common Witchmongers taken to be truths, and falsely ascribed unto Demons, and that they are sufficient grounds to proceed upon to condemn the Confessors to death, when all is but passive delusion, instrinsically wrought in the deprived imaginative faculty. ... . ${ }^{\text {s1 }}$

Such states of melancholy, Webster believed, occurred by means of evil agitation,

40 Dictionary of National Biography, vol. 58, London, 1899, pp. 432-33.

47 Meric Casaubon, Of Credulity and Incredulity, London, 1668.

48 London, 1677." London, 1671.

so John Webster, The Displaying of Supposed Witchcraft, p. 32.

61 Ibid., p. 32. 


\section{Garfield Tourney}

particularly a lack of proper education in regard to God, Scriptures, and the Christian religion as well as 'an atrabilarious Temperament, or a melancholick Complexion and Constitution'.52

Ignorance, irreligion, and a melancholic constitution would lead to a delusion of being a witch, particularly with the added stimulus from the teachings of those who themselves were under a most strong, passive delusion and preached the reality of witchcraft. Such witches then believe that they can perform admirable and impossible things through the help of the devil.

Webster emphasized that he did not deny the existence of witches but that there was no evidence that they made any visible contract with the devil, that the devil does not suck upon their bodies, nor do they have carnal copulation with him. ${ }^{53}$ Furthermore there is no evidence for the existence of familiars, flying from one place to another, or transformation into diverse creatures. He rejected the idea of spectral evidence (apparitions of the devil and his cohorts), and emphasized that although apparitions may occur, there is no basis for the belief that they are necessarily caused by evil spirits. 'There are many Apparitions that are produced by natural and artificial Causes, and need not be referred to supernatural ones ...54. Webster's argument relied primarily on Scripture. '. . . the Sacred Scriptures are the only Medium joyned with sound Reason, of deciding this point of the power and operation of Demons and Witches, and not other improper Mediums brought to by divers Authors.'55 Such authors of course included Glanvill and Casaubon.

He emphasized that the confessions of witches must be rejected because of their defect in reason. 'The Witch must be taken to be either a person insanae, vel sanae mentis; and if they be insanae mentis, their Confessions are no sufficient evidence, nor worthy of any credit; because there is neither Reason, Law, nor Equity that allows the testimony or confession of an Idiot, Lunatic, mad or doting person, because they are not of a right and sound understanding, and not be accounted as compotes mentis, nor governed by rationability.'56

Many of the other phenomena of witchcraft were rejected by Webster. The Witches' Sabbath and transvection were related to melancholia and passive delusions, often augmented by 'soporiferous ointments' that resulted in dreams and hallucinations. ${ }^{57}$ The witches' marks and teats were explained in terms of the pathology well known to physicians and surgeons. ${ }^{58}$ Many of the states of possession were related to malingering, juggling and various types of impostures. The famous Biblical story of the Witch of Endor was regarded as a classical example of imposture. ${ }^{59}$ Although the occurrence of possession in modern times was rejected, he admitted that during the time of Christ demoniacs existed and were exorcised by Him. ${ }^{60}$

Webster believed that Satan can cause diseases by seducing and drawing men to gluttony and drunkenness, which in turn result in many diverse illnesses. Through

ss Ibid., p. 32.

ss Ibid., p. 53.

st Ibid., p. 40.

ss Ibid., p. 43.

so Ibid., p. 66.

67 Ibid., p. 69.

s8 Ibid., p. 82.

so Ibid., p. 167

00 Ibid., p. 239. 


\section{The Physician and Witchcraft in Restoration England}

insatiable lust and concupiscence, venereal diseases develop. At other times the devil pushes men into malice, wrath and various passions in which they wound, lame and sometimes kill one another. ${ }^{61}$ Great pestilences may also be a result of diseases from the devil as well as punishment for sins from God. But the devil is unable to cure diseases, this power coming alone from God. Even though the devil does delude the minds of men into superstitious beliefs, Webster emphasized that there were many occult and wonderful effects wrought by natural causes and agents, such as the power of Sympathetic Powder, a popular remedy of the period. Eventually these phenomena would be understood through study and natural philosophy. ${ }^{62}$

In his own practice Webster never observed witchcraft and possession and emphasized that many physicians have practised for long periods without seeing anything resembling these. 'I that have practised Physick about forty years could never find any such thing in truth and reality, but have known many that have counterfeited these strange vomitings, and the like, which we and others have plainly laid open and detected'. ${ }^{63}$. With examination of the possessed, the peculiar voiding of various objects, convulsions and gesticulations were found to be the result of deception and imposture. He admitted to the efficacy of charms but denied that they had any supernatural power but depended largely on the imagination of patients and the effect of music and words. ${ }^{64}$ Such charms might be very useful for a skilled physician, but for the most part they were largely relied upon by impostors, quacks and the superstitious, and so were best avoided except after careful medical evaluation.

The question can be raised as to why physicians and scientists were not more active in resisting the belief in witchcraft. The matter was not simply one of superstition versus reason, theology versus science, or church versus rationalism, as was often emphasized by the nineteenth-century historians. ${ }^{\circ 5}$ In fact, when witchcraft was criticized by physicians, they did not necessarily attack the basic concepts of the kingdom of Satan and Hell, as seen in the work of Weyer, ${ }^{66}$ Scot, ${ }^{67}$ Cotta, ${ }^{68}$ and Webster. The physician and experimentalist worked within his own framework of study and investigation, but maintained a philosophical orientation similar to those of the period who believed in witchcraft. Some physicians and scientists did not find it necessary to express disbelief in witchcraft, and naturally were reticent in attacking the belief, in order to avoid courting trouble with others on the basis of what was regarded as a secondary issue.

The superstitious state of Restoration Medicine also needs to be emphasized. Value was still attached to the unicorn's horn. Undoubtedly many of the practising physicians were more influenced by the astrological and alchemical ideas of Culpeper ${ }^{60}$ and Blagrave ${ }^{70}$ than by the clinical and observational methods of Sydenham or Willis.

(1) Ibid., p. 231.

c2 Ibid., p. $260-61$.

as Ibid., p. 252.

at Ibid., pp. 331-36.

C6 W. E. H. Lecky, History of the Rise and Influence of the Spirit of Rationalism in Europe, vol. 1, New York, D. Appleton, 1872, pp. 27-154.

60 Johan Weyer, De Praestigiis Daemonum et Incantionibus ac Veneficiis, Basle, 1563.

i7 See footnote 32.

as John Cotta, The Triall of Witcheraft, London, 1616.

co Nicholas Culpeper, The Complete Herbal and the English Physician Enlarged, London, 1653.

70 Joseph Blagrave, Astrological Practice of Physick, London, 1671. 


\section{Garfield Tourney}

Sir Kenelm Digby (1603-1665), who developed an extensive medical practice and was a member of the Royal Society, invented the Sympathetic Powder, a secret formula believed to be of great value in treating many disorders. ${ }^{71}$ Its use was advocated by Sydenham and Webster, among others. Digby also believed in weapon salve and in the aphrodisiac Viperivine, the latter gaining great popularity among the aristocracy. The activities of Greatrakes and his stroking have already been mentioned. Charles II was the most active of the English rulers in carrying out the ritual of the royal touch to treat scrofula, the King's evil; many touchpieces for this were distributed by him. ${ }^{72}$ The thesis of Garrison ${ }^{73}$ that the folkways of medicine are inevitably the same and independent of time, place and circumstance certainly applied to the seventeenth century as they have had relevance for other periods, including our own age. One can see then that many of the beliefs held by the scientific and medical professions were not at all incongruous with the thought of the time. Among the educated as well as the masses the belief in witchcraft was practically universal in the seventeenth century. Individual scientific and philosophical endeavours rather than any concerted advancement in science per se seemed to be important in altering the attitudes.

The decline in witchcraft occurred as a result of many complex factors including the growing change in philosophical orientation reflecting the influence of Hobbes, Descartes and Locke, a re-emphasis of the work of Weyer and Scot in the presentation of Webster, the concern of jurists such as Francis North ${ }^{74}$ and John Holt ${ }^{75}$ regarding the validity of testimony about witches, and a more liberal theology as seen in Bekker's challenge of the idea of Satan's Kingdom. ${ }^{76}$ Hutchinson was one of the first to emphasize the importance of the Royal Society in the decline of superstitious beliefs and witchcraft. But admittedly many of its papers were extremely superstitious and credulous, particularly the interpretations of events remote in time or place. ${ }^{77}$ About its influence Hutchinson stated that 'since that hath been founded, not only our witchcrafts have been banished, but all arts and sciences have been greatly improved'. ${ }^{78}$ Although the Royal Society undoubtedly played a positive force in altering the belief, Hutchinson was writing from the vantage point of 1718 , twenty-five years after the Salem witchcraft episode, in which Cotton Mather, later a corresponding member of the Royal Society, was active.

To conclude, in Restoration England the practice of medicine tended to affirm that all human maladies, including disease, were traceable to God or the devil. The number of atheistic radical physicians, who practised in a completely materialistic framework, was relatively small. For the most part the medical profession had

${ }^{11}$ Lynn Thorndike, A History of Magic and Experimental Science, Seventeenth Century, vol. 7, New York, Columbia University Press, 1958, pp. 498-512.

12 Helen Farquhar, Royal Charities: Angels and Touchpieces for the King's Evil, London, Harrison, 1922, pp. 115-30.

78 Fielding H. Garrison, An Introduction to the History of Medicine, Philadelphia, W. B. Saunders, 1929 , p. 289.

7 Notestein, op. cit., pp. 271-72.

75 John Holt, A Report of All the Cases Determined by Sir John Holt 1681-1710, London, 1738.

78 Balthasar Bekker, The World Bewitched, Eng. trans. from Dutch ed. of 1691 by B. B. A. London, 1695.

${ }^{77}$ This point is well made in the discussion of Increase Mather's credulousness as it was shared by many of the members of the Royal Society. See Kenneth Ballard Murdock, Increase Mather: The Foremost American Puritan, Cambridge, Mass., Harvard University Press, 1925, pp. 173-75.

${ }_{78}$ Hutchinson, op. cit., p. 134. 


\section{The Physician and Witchcraft in Restoration England}

varying degrees of acceptance of a traditional view of divine or diabolic causation of disease, where disease was related to spiritual substance. As often seen historically in cases of demoniacal possession and mental illness, the physician frequently referred the problem entirely to the domain of the clergy. A disease model for the possessed, the deluded, and the melancholic often did not exist within the theoretical framework of the practice of medicine. Though not rejecting divine or diabolic causation, Webster did emphasize the need for viewing a large segment of witches in terms of a disease model related to passive delusions and melancholy. This re-emphasis on the earlier views of Weyer and Scot during this period of literary war regarding the reality of witchcraft led to a sound medical understanding of many of the phenomena of witchcraft, and to a final decline in its belief.

\section{News, Notes and Queries}

\section{THE HARVEY FILM}

The publication of Harvey's De Motu Cordis was an important event in the history of Medicine, so a silent black and white film was made by Sir Thomas Lewis and Sir Henry Dale for the Royal College of Physicians' celebration of its tercentenary in 1928. This was a success, and turned out to be such an excellent demonstration of scientific method, that Sir Henry Dale presented to the College, in 1957 (the third centenary of Harvey's death), a new version of the film, in sound and colour. Besides a great number of individual showings in medical schools and universities all over the world, over 150 copies of the film were sold to such institutions. By 1970 the master copy was worn out, and it was impossible to meet the continuing demand, so in view of subsequent historical researches which have led to a better understanding of the development of Harvey's thought, and of improvements in film technique, it was decided to make a new film.

The film begins with a description of Harvey's education and the teachers who influenced his views. It makes full use of historical documents and portraits, and of sequences specially filmed on location in Padua and England. Then follows an account of the theories of Galen, current in Harvey's time, on the movement of blood in the body: this is presented with animated diagrams. The film continues with the observations which led Harvey to the provisional hypothesis of the circulation, and the rest of the film is concerned with Harvey's experimental work in proof of this hypothesis. The actual experiments are repeated with meticulous care, and the commentary is derived from Harvey's own writings.

The film is in $16 \mathrm{~mm}$. colour, with optical soundtrack: it lasts forty minutes. Exhibition is restricted to medical and educational audiences. Copies are now available for hire or purchase, and modern production techniques make it possible to offer the new film at the advantageous price of $£ 135$ per copy, postage extra. Details can be obtained from the Harveian Librarian, Royal College of Physicians, London NW1. 